\title{
The Proposed Uniform Stock Transfer Act
}

\begin{abstract}
N Act To Make Uniform the Law of Transfer of Tities to Certificates of Stock in Corporations is another of the contributions of Professor Williston to the work of the National Conference of Commissioners on Uniform State Laws. The Stock Transfer Act is one of the commercial series ${ }^{1}$ and was approved by the national conference in 1909,2 after three other drafts had been successively rejected in 1907, 1908, and 1909." Since the conference's ratification of the fourth draft, the Act has become the law of fourteen states. Louisiana, Maryland, and Massachusetts adopted it in 1910; Ohio and Pennsylvania in 1911; Rhode Island in 1912; Alaska, Michigan, New York and Wisconsin in 1913; New Jersey in 1916; Illinois and Tennessee in 1917; and Connecticut in 1918. A bill which would have joined California with these states was introduced at the last session of the legislature but was laid aside because the new law's desirability and extent of the change it would involve in the present codes were not definitely known.
\end{abstract}

The purpose of this article is to present an uncritical exposition of the latter phase of the question rather than any arguments concerning the value of the Uniform Act or the need for legislative innovation in what is now settled law within the state. Two considerations, however, present themselves regarding the proposed law's desirability and may be briefly noted. In the first place, the law governing stock transfers in California is far from being in an unsatisfactory state. Indeed the courts seem to have kept abreast of some of the best considered decisions on disputed matters, so that the Uniform Act, if it be adopted, will work little change in rules which now are governing. In the last analysis, therefore, the question as to whether the Act should be passed is essentially a practical one, first, from the point of view of those whose business it is to deal with transfers, secondly, from the point of view of the individual investor.

1 Other acts included in this work are those aimed at making uniform the law of Sales, Negotiable Instruments, Warehouse Receipts, Bills of Lading, Bankruptcy, Common Carriers of Freight, Credit, Partnership, etc.

2 Reports of American Bar Association (1909), p. 1001.

3 Ibid. p. 1083.

4 Senate bill No. 421, introduced by Senator Carr, Jan. 23, 1919, and referred to the Committee on Judiciary, Feb. 25, 1919. 
To the first of these two classes, aside from the question whether the proposed change will or will not improve local jurisprudence, uniformity should naturally be welcome. A corporation whose business extends through various states and whose stock is sold in a plurality of jurisdictions has had hitherto no convenient guide in aiding it to decide between claimants disputing title to its stock. And while, as a practical matter, a corporation may choose one in preference to the other and assume consciously the peril of having made a mistake, the chances of the latter will be proportionately less when uniform rules in the matter are well established. This applies, of course, only to questions which the Uniform Act decides. In reference to some of the more practical problems, the Act does not purport to be a solution. For example, the perplexing situations arising when a registered owner dies, especially a nonresident owner, are not touched upon, nor are the inheritance tax requirements at all clarified. How far a corporation must watch the limits of a trustee's power is left undecided, while a company's rights against a transferee other than the one actually registered on its books are not defined beyond the present decisions upon the subject. In general, the sort of legislation a California corporation would welcome on the subject of stock transfers is not contained in the Act, and harassed transfer agents will continue to worry, as they have dorie heretofore.

Whether uniformity is so highly necessary as to overcome the objection to the Act which the individual investor also may have is another point to be met. The proposed law proceeds upon the basis that certificates of stock are to be classed with negotiable instruments so far as title thereto is concerned. Thus a thief can convey title (provided, of course, that the certificate is indorsed in blank) even though the unauthorized dealing was in no wise due to the owner's negligence. It has been suggested that such a rule is unobjectionable when applied to short-time commercial paper, ${ }^{5}$ but that outside of certain financial centers like New York city, comparatively few investments in stock are embraced in the use of such stock as collateral, so that on the whole the owner of stock is apt to examine it only at long intervals. Thus dishonest employees will have every opportunity of transferring title to third persons and innocent investors may be mulcted out of their property before they have time to protect themselves. Banks, on the other hand,

5 MacChesney, Uniform State Laws: A Means to Efficiency Consistent with Democracy, p. 54. 
who advance loans on such collateral, can protect themselves by insurance and by examining the source of the borrower's title. No such corresponding protection, as a practical matter, exists for the individual owner, either because he will not ordinarily realize the character of his property, or because, if he does, he will, in nine cases out of ten, fail to take precautionary measures. But it is interesting to note that $\mathrm{Mr}$. MacChesney, president of the Illinois Bar Association, who advanced these objections to the Act when its passage in Illinois was being considered, nevertheless felt that the advantages of uniformity far outweighed his criticism and earnestly recommended that the law be passed by the Illinois legislature, which was done, as stated above, in 1917.

Before the various sections of the Act are considered seriatim, vague statements as to what the Act aims to accomplish should be more definitely explained. Negotiability means a variety of things, and to say that certificates of stock under the Act are placed on an equal footing with other negotiable instruments is apt to be misleading. Improvement in title, suggested above, the abolition of certain corporate liens, and a revolutionary change in the method of attaching shares of stock are the only elements of negotiability which the proposed law involves. A discussion of each of these topics will appear below. Inherent infirmities and original causes of invalidity in a certificate, so far as it is representative of shares in the corporation, are left untouched. That is to say, negotiating a certificate will not, by any authority set forth in the Act, improve the holder's rights, particularly, against the corporation. For such a result, it will be necessary to look to what is already the substantive law of the state derived from other sources.

Nor does the Act undertake to prescribe an exclusive mode of evidencing, as between the parties, a sale and transfer of stock; its object is merely to regulate the mode of transfer on the books of the corporation and to furnish a rule for deciding between claimants when contested ownership is litigated. ${ }^{8}$

Section 1: The first section of the proposed law provides that

o State v. Schofield (1915) 136 La. 702, 67 So. 557 ; but see Wyllys Co. v. Nixon (1914) 165 App. Div. 373, 150 N. Y. Supp. 944 (semble) contra. This would seem to be the sense of the Act considered in its entirety, notwithstanding the use of the word "only" in this section. Thus $\$ 4$, infra, p. 192, recognizes a method of transferring title other than by delivery of the certificate, viz. by separate writing, but makes such a transfer defeasible in favor of a transferee of the certificate. In such a case, $\S 10$, infra, p. 197, gives the defeated purchaser under a separate assignment a remedy in contract against the transferor. 
title to a certificate may be transferred by indorsement and delivery, or by separate assignment and delivery of the certificate.

According to section 324 of the Civil Code, California requires an indorsement and delivery plus a transfer on the books of the corporation to make the sale valid as to third parties. The phrase "third parties," however, has been judicially interpreted to mean only bona fide purchasers." And the same rule applies where a pledge only is made. ${ }^{8}$ Thus in California, persons who buy stock with notice of a prior assignment cannot rely upon the language of the Code, notwithstanding that they make their purchase from one who appears on the corporate books as owner. ${ }^{9}$

The Uniform Act, then, makes only one change. Recording on the company's books is, in any event with reference to this particular point, unessential, the transfer of the certificate itself being sufficient. To that document alone need the transferee look. And because the certificate and not the corporation books is stressed by the new Act, a transferee, under the Act, cannot rely on the books alone to clothe himself with bona fides. ${ }^{10}$

The section under discussion also provides that its provisions shall be applicable although the charter or articles of incorporation of the corporation issuing the certificate and the certificate itself provide that the shares represented thereby shall be transferable only on the books of the corporation or registered by a registrar or transferred by a transfer agent. This is already law in California. ${ }^{11}$

7 National Bank of Pacific v. Western Pacific R. R. Co. (1910) 157 Cal. 573, 108 Pac. 676, 27 L. R. A. (N. S.) 987, 21 Ann. Cas. 1391.

${ }^{8}$ Spreckels v. Nevada Bank (1896) 113 Cal. 272, 45 Pac. 329, 33 L. R. A. 459, 54 Am. St. Rep. 348.

${ }^{\circ}$ Supra, n. 7 and see infra, n. 31. For law governing attachments and executions sales see infra, p. $199 \mathrm{ff}$.

${ }_{10}$ It seems that this would also be the law in California. Absence of the certificate ought, on principle, to put a purchaser on inquiry. But see infra p. 199 and n. 46 . While $\$ 1$ of the new Act would replace $\$ 324$ of the Civil Code, it seems unnecessary to add that, should the Act be adopted, that part of the latter section dealing with stock in water companies should be retained on account of the peculiar nature of such organizations and the need for special rules governing the ownership and transfer of shares in them. Such a reservation was made in the bill introduced in 1919, supra, $n$. 4 . 11 The Western Pacific Co. case, supra, n. 7, holds "the certificate
here in question recited that it was transferable only on the books of the company and on surrender of the certificate. This did not affect the transfer. The right to sell, transfer or pledge corporate stcck is given by statute, and it cannot be curtailed by a recital in the certificate. The recital served to give notice of the rights of the corporation under the statute with respect to transfers, but it did nct change the, relative rights of the stockholder and third persons." See also Riverside Land Co. v. Jarvis (1917) 174 Cal. 316 at 327, 163 Pac. 54; Harvey v. Stowe (1914) 219 Fed. 17, 134 C. C. A. 635;

(1916) 241 U. S. 199, 60 L. Ed. 953, 26 Sup. Ct. Rep. 541. This section of the Act and the present law in California mean only that a corporation cannot 
Section 2: This is a preventive measure to the effect that nothing in the Act is to be construed as enlarging the powers of an infant or other person lacking full legal capacity, a trustee, executor, administrator, etc. ${ }^{12} A$ fortiori, existing law will not be changed.

Section 3 is also preventive. Under this section, a corporation may still recognize the person who appears on its books as owner as entitled to dividends and may hold that individual liable for calls and assessments. This also is already law in California. Section

prevent a shareholder from transferring what he owns to another person. Thus when tre dispute is only between transferor and transferee over title, recitals on the certificate and corporate by-laws and resolutions become unimportant. This situation must be distinguished, however, from that wherein the corporation refuses to recognize the transferee as a stockholder by refusing to transfer on its books stock he has purchased, basing their refusal on corporate restrictions in existence at the time. See infra p. 199.

12 See infra, n. 31, for a comment on the power of a trustee under the present law. As was suggested supra, p. 187, it is evident that the Uniform Act contains nothing which will aid a co:poration called upon to make transfers following an owner's death. A few of the problems involved may be briefly indicated. (a) When an owner of stock in California dies, his executor or administrator, being entitled under $\$ 1452$, Code of Civil Procedure to possession of his personal property, can effect a transfer of such stock upon the books of the corporation, upon a proper showing of his position as representative of the deceased. These transfers are, of course, made to the demandant in the latter's representative capacity only. But a corporation must first obtain the consent of the state comptroller before such a procedure is possible, for $\S 13$ of the Inheritance Tax Act of 1917, Cal. Stats. 1917, p. 880 , provides that in all cases no transfer of stock belonging to or standing in the name of a decedent (thus irrespective of twho demands it) shall be made unless such consent is first obtained. By this means, the state protects itself in the collection of its inheritance tax. Presumably, if a corporation transfers stock after the death of the registered owner (say where the certificate is indorsed in blank prior to death) without notice of the death, it would not incur the severe penalty $(\$ 20,000)$ which a violation of this tax regulation entails, but the langtrage of the provision is general and a judicial interpretation of it might make it as drastic as is suggested. Ought not a transfer agent then in every case when called upon to make a transfer ascertain whether the registered owner is still alive?

(b) Complications likewise arise when a non-resident owner of stock in a domestic corporation dies. If ancillary letters of administration have not been taken out, a corporation may safely transfer to the person who proves his right uuder the domiciliary administration. Union Trust Co. v. Pacific Tel. \& T Tel. Co. (1916) 31 Cal. App. 64, 159 Pac. 820; and see Murphy v. Krause (1901) 135 Cal. 14, 66 Pac, 971, 88 Am. St. Rep. 90.

But suppose that ancillary letters have been issued and the corporation does not know of that fact. Will 'a showing of due diligence on its part be sufficient? Will an affidavit by one who affirms an acquaintance with all the affairs of the domiciliary administration to the effect that no ancillary letters have been applied for or issued be enough to protect the local corporation, or is it necessary to examine the records of every county in the. state before such a transfer is made? See Maas v. German Savings Bank (1903) 176 N. Y. 377,68 N. E. 658,98 Am. St. Rep. 689 , holding that where the ancillary administrator delayed in giving notice of his appointment to a foreign bank in which the deceased was a depositor, the bank was protected in making payment to the domiciliary administrator and that the record of the appointment of the ancillary administrator was not of itself constructive notice. 
324 of the Civil Code provides a statutory method of transferring shares, but from the cases upon the subject, the language of this section of the new act is applicable today in California in favor of corporations. Thus, while dividends follow legal title and go to the one who holds that title when the dividend accrues, ${ }^{18}$ a corporation, in the absence of notice, is privileged not to account to anyone other than the registered owner. ${ }^{14}$ Likewise in levying assessments, a corporation may look only to the list of stockholders as their names are registered upon the books, although they may already have sold their stock (and on that account have an action over against the transferees. $)^{15}$

Although statutory liability of stockholders is not mentioned in the Act and cannot be affected, it would have fallen in the same category. Consequently, while a stockholder's liability is not limited to those alone who appear on the books but includes every equitable owner, ${ }^{16}$ those whose names do appear incur the liability even though they are not the owners, ${ }^{17}$ in the absence of proof that

13 Dow v. Gould \& Curry S. M. Co. (1867) 31 Cal. 629, 649; Schroeder v. Pissis (1900) 128 Cal. 209, 60 Pac. 758.

14 Ashton v. Zeila Mining Co. (1901) 134 .Cal., 408, 410, 66 Pac. 494; and see also L. R. A. 1917B 329.

15 Visalia etc. R. R. Co. v. Hyde (1895) 110 Cal. 632, 43 Pac. 10, 52 Am. St. Rep. 136; and see also People's Home Savings Bank v. Stadtmuller (1906) $150 \mathrm{Cal}$. 106, $88 \mathrm{Pac}$. 280 where, it seems, a corporation could not proceed to collect calls for unpaid subscriptions from a transferee of stock who did not have the same transferred to his name on the books of the company, in the absence of some sort of equitable estoppel, as where he had accepted and receipted for dividends, voted at meetings, or in various other ways had exercised a stockholder's privilege.

Probably the same result would be reached where an assessment for ordinary business debts was levied. In case, therefore, the court decided that the unregistered transferee could not be sued and the registered transferor was either judgment-proof, or, as often happens, a claim against his estate has not been filed, it becomes important to ascertain whether the corporation may not proceed against the stock itself to satisfy the call. See infra p. 200, for some discussion of this situation in connection with $\S 15$ of the Uniform Act.

18 Hughes Mftg. Co. v. Wilson (1910) 13 Cal. App. 22, 108 Pac. 87; Western Pacific R. R. Co. v. Godfrey (1913) 166 Cal. 346, 136 Pac. 284, Ann. Cas. 1915B 825.

17 Baines v. Babcock (1892) 95 Cal. 581, 27 Pac. 674, 29 Am. St. Rep. 158. This case holds that "one to whom stock is issued by the corporation and who has the same placed in his name on the books of the corporation and who is liable to the creditor of the corporation as though he were the absolute owner; and this whether he was in fact a pledgee, agent, or trustee for the real owner."

And note that in banking corporations, stock books and public notice of transfers are by statute declared to be conclusive evidence of ownership. See Cal. Civ. Code, § 331, and Hurlburt v. Arthur (1903) 140 Cal. 103, 73 Pac. 734. 
they were not guilty of laches in having their names removed, that their names appear without their knowledge or consent. ${ }^{10}$

So far as voting stock is concerned, section 312, Civil Code, requiring registration of stock ten days in advance will remain unchanged, as will also section 307 governing voting privileges when a pledge is made. ${ }^{20}$

This section of the Uniform Act, then, is far from revolutionary. The negative form in which it is cast simply indicates that registration of a transfer on the corporate books is essential before the holder of legal title to a share comes in privity with the corporation and becomes a stockholder therein in the fullest sense and entitled to the benefits such a position affords. From the foregoing cases, such is also the California rule.

Section 4 of the Act briefly stated amounts to this: title derived through a certificate extinguishes title derived through a separate document. Thus the owner of a certificate who sells the same to another by a separate writing but does not deliver the certificate to his transferee retains a power, before the certificate is surrendered to the corporation issuing it, of negotiating the same to a bona fide purchaser who, taking possession of the certificate properly indorsed by the person appearing thereon to be the owner, will prevail over the first buyer. This provision is of course consistent with what the whole Act aims to accomplish-the importance of using the certificate itself as opposed to other methods of transfer.

It is not believed that this would change the local law. From the language of section 324, of the Civil Code, it would appear that indorsement and delivery of the certificate itself was the only method of transferring a share of stock in California. This, however, is not the case. Although Taft v. Presidio, etc. Railroad Company ${ }^{21}$ seems to indicate that the statute must be followed, the court in Nicholls v. Reid ${ }^{22}$ intimates that any other deraignment of title would be efficacious, while a still later decision ${ }^{23}$ states that

18 Welch v. Gillelen (1905) 147 Cal. 571, 82 Pac. 248; Shattuck and Desmond etc. Co. v. Gillelen (1908) 154 Cal. 778, 99 Pac. 348.

19 Shattuck etc. Co. v. Gillelen, supra, n. 18; Shean v. Cook (1919) 180 Cal. 92, 179 Pac. 185.

$20 \mathrm{~A}$ pledgor of stock has right to vote it unless this right be conferred upon the pledgee by special agreement: Dulin v. Pacific Wood and C. Co. (1894) 103 Cal. 357, 363, 364, 35 Pac. 1045.

21 (1890) 84 Cal. 131, 24 Pac. 436, 18 Am. St. Rep. 166, 11 L. R. A. 125, 3

Cal. Unrep. Cas. 152.

22 (1895) 109 Cal. 630, 42 Pac. 298.

23 Hall v. Cayot (1903) $141 \mathrm{Cal} .13,74 \cdot$ Pac. 299. And see Tregear v. Etiwanda Water Co. (1888) 76 Cal. 537, 18 Pac. 658, 9 Am. St. Rep. 245. 
if a transfer of shares (as security in this case) is "imperfect by reason of the absence of indorsement or other writing signed by the debtor; equity will, in the absence of intervening rights of third parties, looking at the intent rather than form, treat the subjectmatter . . . in the same manner as if the final acts contemplated by the parties had been executed as they ought to have been." A comparatively recent case ${ }^{24}$ seems to consider the code section as permissive and not mandatory and sets forth the following:

"A share of stock being an incorporeal right, incapable of manual delivery, and the certificate being nothing more than evidence of its existence, it is obvious that, in the absence of any controlling statutory inhibition, the shares, without an assignment or delivery of the certificate, may be assigned in any manner appropriate to the transfer of incorporeal personal property, as, for example, by bill of sale, or any mode that will suffice to pass title to a chose in action or intangible property. The jus disponendi in shares of stock is an incident of ownership and may be exercised in any manner not prohibited by law. .... We are satisfied that .... transfer of title, good as between the parties thereto, may be made in a manner other than that recognized as a lawful mode of transfer by section $324 .{ }^{25}$

It seems unquestioned, therefore, that between the parties title to stock may be transferred without delivery of the certificate. It seems, too, to admit of little doubt but that California courts would protect an intervening bona fide purchaser of the certificate, were the case presented to them, just as the Uniform Act does in so many words. ${ }^{26}$

According to section 5 of the new law, if a certificate is indorsed by the apparent owner, delivery of it is effectual to pass title (in the absence of notice and failure to give value), although the one who makes the delivery has neither the right. of possession nor authority from the owner.

This section undoubtedly goes further than the law as it stands today in the state in that it allows even a thief to transfer title. To be sure, a stock certificate, in California, is negotiable to the extent

24 Young v. New Pedrara Onyx Co. (1920) 32 Cal. App. Dec. 439, 192 Pac. 55, citing Riverside Land Co. v. Jarvis, supra, n. 11.

25 And see Spangenberg v. Nesbit (1913) 22 Cal. App. 274, 134 Pac. 343, where stock was sold by separate contract of sale and went unquestioned; also Geary St. Park and Ocean R. R. Co. v. Bradbury Estate Co. (1918) $179 \mathrm{Cal}$. 46, 175 Pac. 457, where stock was sold by separate bill of sale.

${ }_{26}$ Note reference to third parties in Hall v. Cayót, supra, n. 23, and quotation therefrom at the top of this page and the emphasis in the New Pedrara case placed on the fact that such a transfer would be good only between the parties. 
that one who is intrusted with possession of a certificate, properly indorsed to him, may sell or hypothecate it so as to block off the true owner. This result is based upon the principles of cstoppel. But Fowles v. National Bank of California, ${ }^{27}$ which reviews the authorities in the state and announced this rule (thus following the New York decision of McNeil v. 10th National Bank), ${ }^{28}$ expressly distinguished the case where a stolen certificate was assumed to be transferred by the thief, saying that under such circumstances the transferee would take nothing. This had already been decided in Barstow v. Savage Mining Company. ${ }^{29}$ The Fowles case, of course, limits the efficacy of possession when it holds that

"where the ownership of the person dealing with personal property as his own is evidenced by his possession only, a purchaser or pledgee from such person takes subject to the rights of the true owner, even though he be a bona fide purchaser or pledgee for value, and the rule above does not apply. But where such person has not only the possession, but also written indicia of ownership with which he has been voluntarily furnished by the true owner, the principle is applicable."

It is obvious that a thief who gains possession of a certificate indorsed in blank has as much written indicia of ownership as one voluntarily intrusted with possession of a document so indorsed. The certificate, to a bona fide purchaser, would appear the same in each instance. Ex hypothesi, he will have no knowledge of the voluntary or involuntary character of the previous transfer of possession or the existence or non-existence of fault or negligence on the previous owner's part. The Uniform Act refuses to make a purchaser's title depend upon the contingency of a previous intrustment or prior fault and gives him superior rights in either case. ${ }^{30}$

But this section of the Act probably does not affect the limitation on possession which the Fowles case sets forth. Before the true owner of a certificate is cut off, some sort of indorsement is necessary. There is nothing in the Act that allows a certificate to pass from hand to hand without indorsement, if such is necessary to its negotiation, so that a transferee could claim the benefit of an improvement in title. Indeed, it would seem that in the absence

27 (1914) 167 Cal. 653, 140 Pac. 271.

38 (1871) 46 N. Y. 325, 7 Am. Rep. 341.

29 (1883) 64 Cal. 388, 1 Pac. 349, 49 Am. Rep. 705; and see Kohn v. Sac'to Electric, Gas and Ry. Co. (1914) 168 Cal. 1, 141 Pac. 626.

30 This is the rule of the Uniform Bills of Lading Act, Cal. Civ. Code, $\S 2129 \mathrm{C}$; also of the Uniform Negotiable Instruments Act, Cal. Civ. Code, $\$ \S 3090,3138$. The Uniform Sales Act (not yet adopted in California) requires an intrustment; see $\$ 32$ thereof; so, too, does the Uniform Warehouse Receipts Act according to $\S 42$ thereof. 
of such an indorsement such a transferee could not claim to be bona fide. ${ }^{31}$

Sections 6 and 7 make fraud, duress, mistake, revocation of delivery or authority, death or legal incapacity after indorsement (either before or after delivery), absence of consideration-all of these-ineffectual in vitiating an indorsement. Rescission of a transfer is of course, possible under such circumstances if, in the meantime, negotiation of the certificate to a bona fide purchaser has not occurred or the injured party waived the injury or has been guilty of laches in pursuing his remedy. And even after rescission, section 8 of the Act protects a bona fide purchaser, if the transferee retains possession of the certificate or has a new one representing the same shares and transfers it to such a purchaser.

It is obvious that the first of these sections states that by the indorsement a juristic act is accomplished and a power conferred upon the indorsee, of selling, whether wrongfully or not, to one who, if he purchases in good faith, will have rights superior to the injured party. The next section allows rescission but the last section requires that that right must be exercised before third party rights intervene.

These sections will work no radical change in the present law. The decisions epitomized in the Fowles case, heretofore noted, already apply the principles of estoppel in favor of a bona fide purchaser of a share from a wrongdoer who has not title, while the law governing sales of personal property can be resorted to for the purpose of protecting such a purchaser from the effect of latent equities between transferees in the chain of indorsers. That is to say, considering a share of stock personal property, ${ }^{32}$ if the

s1 But where one is registercd as trustce or indorses as trustce, a purchaser is not put upon notice. This was held to be the law in N. W'. Portland Cement Co. v. Atlantic Cement Co. (1916) 174 Cal. 308, 163 Pac. 47. This decision puts a corporation in a difficult position so far as making a transfer on its books is concerned. If it doubts the trustee's power of sale and therefore fears liability at the hands of the beneficial owner if it makes a transfer in derogation of the latter's interest, but at the same time, with this case to guide him, the transferee claims to be bona fide and demands a transfer, and the corporation knows of its liability to him if what he says is truc, it is apparent that a transfer agent must have the wisdom of a Solomon if he would protect his company's interest. Interpleading is unsatisfactory, but seems to be the only course open. How far must a corporation go in watching the power of trustees in whose name stock stands on its books?

Of course, the fact that shares of stock stand on the books of the corporation in the name of one other than the holder of the certificate covering such stock, where such certificate was indorsed in blank is not sufficient to put one on notice that the holder of such certificate is not the owner of the stock. Hellman etc. Bank v. Armstrong (1919) 39 Cal. App. 483, 179 Pac. 432.

${ }_{32}$ Cal. Civ. Code, $\$ 324$. 
owner be defrauded out of it or induced to sell it under such circumstances that the sale would ordinarily be considered inequitable and capable of being rescinded, an exercise of such a right of rescission a fortiori presumes a passage of title. This being so, all the consequences of an ordinary sale apply, so far as the rights of a bona fide purchaser before rescission are involved. It is well settled that rescission of the passage of title to personal property must be effected before title is conveyed further to a purchaser for value without notice. ${ }^{33}$

It might be well to note in passing that neither of these considerations is peculiarly and distinctively characteristic of negotiability. The sections under discussion have no reference to fraud and the various other infirmities which may attach to a share of stock at its source but apply only to such defenses as they arise in the deraignment of title. ${ }^{34}$

Section 9 allows a transferee of stock an action to enforce specifically the transferor's obligation to indorse, if an intent to transfer title is made out and possession of the certificate has been delivered without the necessary indorsement.

In California, stock must be of peculiar value before a contract regarding its transfer will be specifically enforced. ${ }^{35}$ While this is true, it will be noted that this section refers not so much to the specific execution of the transfer itself as to providing the vendee of stock with proper evidence of his title. California law allows a transferee, by a suit in equity, to compel a corporation to transfer stock to him, irrespective of the sort of stock involved. ${ }^{36}$ It seems that equity takes jurisdiction by implying a trust between the corporation and the person demanding the transfer. It would not be stretching this assumption of jurisdiction too far to cover the step just prior to the transfer on the books, namely, the transferor's indorsement to his vendee. Title having passed by contract, the

33 Sargent v. Sturm (1863) 23 Cal. 359, 83 Am. Dec. 118; Thornton v. Hook (1868) 36 Cal. 223, 229; Cal. Cured Fruit Assoc. v. Stelling (1904) 141 Cal. 713, 75 Pac. 320; Wendling Lumber Co. v. Glenwood Lumber Co. (1908)

153 Cal. 411, 95 Pac. 1029; People v. Cal. Safe Deposit and Trust Co. (1912)

19 Cal. App. 414, 126 Pac. 516, 520 (subscription to stock).

34 Cf., supra, p. 188.

35 Treasurer v. Comm. Gold Mining Co. (1863) 23 Cal. 390, 393.

36 Spangenberg v. Western Heavy Hardware and Iron Co. (1913) 166 Cal. 284, $135 \mathrm{Pac}$. 1127; and see note in $133 \mathrm{Am}$. St. Rep. 723 to State v. Jumbo Extension Min. Co. (1908) $30 \mathrm{Nev}, 192,94 \mathrm{Pac}$. 74, 16 Ann. Cas. 896. Other remedies against a corporation for failing to register stock include a suit to collect the statutory penalty provided for by $\$ 324$ of the Civil Code and a suit for conversion: Kimball v. Union Water Co. (1872) 44 Cal, 173, 13 Am. Rep. 157. 
transferee owns the stock and is entitled to such evidence of his ownership from his vendor as is necessary to the full enjoyment of the subject of sale. Equity could easily construe a fiduciary relation for the purpose of compelling such indorsement. Local courts would undoubtedly go this far, so it cannot be said that the present section would change the law now in existence. Once such a fiduciary relation is established it is of course unnecessary to establish inadequacy of legal remedy. ${ }^{37}$

This section also provides that if the indorsement is compelled, it takes effect as of the date of actual making. This is inserted for the protection of those who may purchase the certificate before the rights of the owner are settled.

Section 10 makes an attempted transfer of title without delivery equivalent to a promise to transfer with the obligations to be imposed thereby to be determined by the law governing the performance of contracts.

Section 11 sets forth the warranties upon which a transferor of a certificate is liable. Providing the transfer is for value, he is held to warrant:

(a) That the certificate is genuine,

(b) That he has a legal right to transfer it, and

(c) That he has no knowledge of any fact which would impair the validity of the certificate.

These warranties are also made by the assignor of a claim secured by a certificate, though liability in this last is limited to the amount of the claim.

With reference to transfers of stock hitherto made in California it has been said that the rules of caveat emptor apply. ${ }^{38}$ This statement was made in a discussion of the question of a certificate's negotiability, and if it can be taken to refer to warranties involved in a stock transfer, it is undoubtedly incorrect. Although the question as such of warranties in stock sales has not been before the courts of California, there seems to be no reason why statutory warranties applicable in sales of personal property would not be equally pertinent when one sells stock. Thus section 1765 of the Civil Code makes one who sells personal property warrant that he has a good and unencumbered title thereto. Ordinarily, such a warranty of title has been regarded in other jurisdictions in connection with stock sales as necessarily importing the existence of

37 Bacon v. Grosse (1913) 165 Cal. 481, 132 Pac. 1027.

as Ramage v. Gould (1917) 176 Cal. 746, 749, 169 Fac. 670. 
the thing sold, namely the shares.3v Warranty of title is then held to mean that the transferor owns something other than meaningless paper certificates. In other words, existence and therefore genuineness is warranted. If this be also the rule which the California courts would follow if the case came before them, it is evident that the Uniform Act makes little change, two of the warranties there involved being included in what has just been said.

But some courts in endeavoring to describe accurately the nature of a share of stock have said that it partakes of the nature of a chose in action for one reason or another. ${ }^{40}$ In California, when a non-negotiable chose in action is assigned, only one implied warranty is considered as existing, namely, that the assignor has no knowledge of facts tending to prove the instrument worthless. This is construed from section 1774 of the Civil Code applying such a warranty to written instruments. This section has been held to be exclusive. ${ }^{* 1}$ It is unlikely that a share of stock would fall within the same category, as the Code section mentioned refers only to instruments in writing purporting to bind one to the performance of an act; but if such a construction should be made, it is evident that the two other warranties suggested above as being applicable would be cut off. It would be desirable to have the warranty which this section embodies, but not its limitation. The Uniform Act reaches this result by incorporating the warranty of the section with the other two.

The Act is silent as to whether these warranties run in favor of remote assignees of certificates, and it is probable that only judicial legislation would make them so run.

Section 12 limits one possible effect which the preceding section may have otherwise had. One who holds a certificate as security and demands payment of the obligation it was designed to secure does not warrant to the person who makes the payment (whether a party to a draft drawn for such debt, or any other person) that the certificate is genuine, or that the shares represented thereby are valuable. Without such a limitation, a creditor might have found himself in the unenviable position of incurring liability on a warranty by simply gaining what he insisted upon, namely the amount due him from his debtor.

30 See notes in 53 L. R. A. 153 and 10 Ann. Cas. 168.

40 Lawler v. Kell (1897) 6 Ohio E. \& C. P1. Dec. 311, 4 Ohio N. P. 218; Herbert v. Simson (1915) 220 Mass. 480, 108 N. E. 65, I. R. A. 1915D 733; Young v. New'Pedrara Onyx Min. Co. supra n. 24; Clarke on California Corporations, p. 307.

\$1 Sutro v. Rhodes (1891) 92 Cal. 117, 28 Pac. 98. 
Section 13 is the provision which will work the most radical change in California law as it now stands, and upon the desirability or undesirability of the change, the Act's adoption will probably stand or fall. Attaching stock of a debtor on the books of the corporation has been a familiar practice in California..2 Once the attachment is made, although prior unregistered transfers will not be defeated, ${ }^{42}$ subsequent assignments of the certificate will be ineffective. ${ }^{44}$ So, too, levying execution on stock attached on corporate books and an execution sale thereof will bestow upon a bona fide purchaser at the sale a title superior to intervening assignees of the certificate. ${ }^{45}$ And it is even possible for the creditor himself to become such a purchaser.to

The Uniform Act wipes out this entire practice. Under the Act, no attachment or levy upon the shares is valid unless the certificate itself be seized or surrendered to the corporation or its transfer by the holder enjoined. While section 14 is designed to empower courts to give necessary aid in reaching the certificate, it goes without saying that an attaching process requiring a creditor to go this far and not allowing him to stop with the corporate books will be extremely difficult of application, and, it may be, so impractical as to remove this class of property from a creditor's reach entirely. But such a rule is quite consistent with what the Act aims to accomplish-negotiability, so far as title is concerned, of the certificate representing the shares, without the limitations involved in compulsory reference to company books. Negotiability of this sort cannot easily exist side by side with the present local attaching process.

If the Act is adopted, subdivision 4 of section 542 of the Code of Civil Procedure should be changed to provide a method of attaching consistent with the new law. Under the existing law, stock has been considered as personal property incapable of manual delivery so that under section 669 of the Code of Civil Procedure the practice has been to give an execution purchaser a certificate of sale, which certificate suffices to entitle the purchaser

42 Cal. Code Civ. Proc. $\$ \S 541,542-4,699$.

45 National Bank of Pacific v. Western Pacific R. R. Co., supra, n. 7.

14 Ramage v. Gould, supra n. 38; Bowring v. Prime (1920) 31 Cal. App. Dec. 767, $189^{\prime}$ Pac. 701.

45 West Coast S. F. Co. v. Wulff (1901) 133 Cal. 315, 316, 317, 65 Pac. 622, 85 Am. St. Rep. 171 ; Security Comm. \& Sav. Bank of El Centro v. Imperial Water Co. No. 1 (1920) 60 Cal. Dec. 175, 192 Pac. 22.

10 American Trust \& Banking Co. v. Union Security Co. (1919) 29 Cal. App. Dec. 729, 184 Pac. 508. 
to have a new certificate issued to him by the corporation. The new Act, however, justifies the corporation in refusing to issue a new certificate until the old certificate is surrendered. Thus, 2 mere certificate of sale from a sheriff will not ordinarily be sufficient if the new law comes into existence. ${ }^{47}$

Section 15 prohibits a lien in favor of a corporation upon the shares represented by a certificate issued by such corporation and provides that there shall be no restriction upon the transfer of shares represented, by virtue of any by-law of such corporation, or otherwise, unless the right of the corporation to such lien or the restriction is stated upon the certificate.

Certainly as a matter of practice in California it has been customary for corporations to restrict transfers of stock so as to protect themselves on debts due from registered owners. This is usually intended to be accomplished by provisions in the articles of association, or by appropriate by-laws, or by notation of such restriction on the certificate itself with or without the former provisions. To ascertain what change this section of the new Act will cause will require some consideration of the present decisions upon the subject, and for the purpose of such consideration it will be necessary to treat separately (a) debts due for ordinary transactions, as where a corporation advances money with its own stock as security; (b) assessments levied by the corporation for ordinary business purposes; and (c) liability on calls for unpaid subscriptions.

(a) In regard to the first of these situations, in Anglo-California Bank v. Granger's Bank, ,8 $^{48}$ restrictive by-law was passed, but because the court doubted the power of the corporation to pass such a by-law in view of the statutory method provided for transferring stock, and because the restriction was not noted

47 At present the practice is simply to present the certificate of sale obtained from the sheriff to the corporation and to obtain on the strength of it a new certificate for the shares indicated on the books as belonging to the execution debtor. When a new certificate is issued, note that there will then be more than one outstanding certificate for the same shares of stock. However, the rule of the case cited in the preceding note protects the corporation from liability to the transferee of the old certificate. The Uniform Act would of course abolish this procedure.

48 (1883) 63 Cal. 539 ; and see 39 L. R. A. (N. S.) 293. One case in a Federal court construing California law held that such a power existed. This case was decided thirteen years before the Anglo Bank case and the latter did not refer to it: Pendergast v. Bank of Stockton (1871) 2 Sawy. 108, Fed. Cas. No. 10, 918, 4 Am. L. T. Rep. 247, 6 Am. Law. Rec. 574. 
on the certificate, it was held that a purchaser of the certificate without notice could properly demand that a transfer be made to him and that the corporation converted the stock by claiming a lien for a debt due from the prior registered owner. Not only was no lien held to exist, but negotiation under such circumstances was held to impose no liability at all upon the transferee without actual notice

But it is possible to create such a lien upon stock by contract between the corporation and the stockholder. When that contract is noted upon the face of the certificate, a purchaser thereof must take with notice of its terms and cannot demand a transfer until the debt to the corporation is paid. This was the result reached in Jennings v. Bank of California ${ }^{49}$ and Ralston v. Bank of California. ${ }^{50}$ Both of these decisions impress the importance of notice and neither of them is authority for the proposition that the existence of the by-law itself, without more, binds the transferee. The Jennings case expressly recognizes the rule of the Anglo Bank case, supra, and distinguishes it on the grounds that there no notice was placed upon the certificate.

(b) For assessments levied for the purpose of paying debts and expenses incurred in conducting the corporation's business, a general lien exists by statute. ${ }^{51}$ According to Lankershim Ranch Land Co. v. Herberger, ${ }^{52}$ this is the only lien not dependent upon possession given a corporation by statute. Clearly, no notation with regard to it is required upon a certificate.

(c) An analysis of the question of unpaid subscriptions to stock in California requires that the distinction be borne in mind between the corporate lien to secure the payment of such subscriptions and the right on the corporation's part to collect them at all. Thus under section 323 of the Civil Code, unless the fact of partial payment is noted on the certificate itself, it would seem there will be no obligation on the part of the transferee of the certificate to

19 (1889) 79 Cal. 323, 21 Pac. 852, 12 Am. St. Rep. 145, 5 L. R. A. 233; and see 39 L. R. A. (N. S.) 293.

50 (1896) 112 Cal. 208, 44 Pac. 476.

51 Cal. Civ. Code, $\S \S 331-339$.

s2 (1890) 82 Cal. 600, 23 Pac. 134., 
meet the calls, if he buys without notice ${ }^{53}$ and a fortiori, no lien. On the other hand, if the right of the corporation to charge a transferee of the certificate is admitted, say in the case where, although no notation appeared on the face of the certificate as required by the Code, at the same time the transferee bought with notice of his liability, the question whether a lien upon the shares exists in California is a matter upon which one recent case at least throws some doubt. Thus in the Lankershim case noted hitherto ${ }^{54}$ the corporation merely proceeded to collect what was still due on some shares, and it was held that no lien existed; on the other hand, in Geary St. Park and Ocean Railroad Company v. Bradbury Estate Company, ${ }^{55}$ because no claim had been filed against the defendant estate and hence no personal liability could be enforced and because the call was made apparently in the nature of an assessment to pay outstanding corporate debts, the court, without citing the Lankershim case, assumed that a sale of shares to satisfy the call was possible.

What change, therefore, will the Uniform Act make in these matters? In reference to (a), the first situation noted above, it seems that the cases do not justify what is undoubtedly common practice, i. e., passing a by-law or making provisions restricting transfers in the articles of incorporation, without corresponding notations upon the certificate. Under the Act, in all cases of this sort, the restriction must be noted. California law, but not the

53 Rhode v. Dock-Hop Co. (1920) 60 Cal. Dec. 599, 194 Pac. 11 (semble). Before $\$ 323$ of the Civil Code was amended, liability for calls for uupaid subscriptions passed with the shares to the transferee thereof even though he purchased without notice: Perkins v. Cowles (1910) 157 Cal. 625, 108 Pac. 711, 137 Am. St. Rep. 158, 30 L. R. A. (N. S.) 283. Where stock is issued, not purporting to be fully paid up, a coutract right exists in favor of the corporation against the stockholder which may or may not in view of this code section, be enforcible against the transferee of the share, according as the latter takes it with or without notice. And it seems that in enforcing this right a creditor will stand in no better position than the corporation itself. Where, however, stock is issued as fully paid, between the corporation and the stockholder, obviously no such contract right can exist and whether any obligation to make further payments can be enforced against the original subscriber will depend upon other legal-principles, namely fratd and its allied theories. The liability of a transferee will likewise depend upon similar considerations. Wiith the exception of the necessary implications of $\$ 15$, the Uniform Act does not purport to deal with such situations, emphasizing as it does questions concerned with the transmutation of title between individuals and negotiability in reference to that point alone. For a discussion of the distinction indicated, namely the distinction between unpaid and watered stock see comment on the Rhode case, this issue, p. 238.

si Supra, n. 52.

5s Supra, n. 25. 
practice, seems to have reached this result already. So far as (b), assessments for ordinary business purposes, is concerned, it may well be doubted whether, even under the Act, it will be necessary to note upon a certificate that it is subject to a lien for such purposes. As a common-sense matter, a purchaser of stock need not be told that a corporation has a power of declaring assessments upon stock and that the stock itself will go to meet such calls if the amount of the levy is not paid. But the language of this section is such that under it it would be safe nevertheless to make a notation on the certificate. As to (c), the rule of the Lankershim case, supra, so far as it deals with liens to satisfy unpaid subscriptions, will be restored by the Act. Without a notation on the certificate it will be impossible for a corporation to sell the stock and apply the amount received on the subscription debt.

Under section 16, the alteration of a certificate, whether fraudulent or not, and by whomsoever made, shall not deprive the owner of his title to the certificate and the shares originally represented thereby, and the transfer of such certificate shall convey to the transferee a good title to the certificate and the original shares.

Although the Act is silent upon the effect of a forged indorsement, it would not seem that this section has reference to such a situation, for alteration generally means a change in the body of the instrument as opposed to the addition of spurious signatures. Thus the present rule that in some situations an owner may be deprived of his stock but given in lieu thereof certain rights of action will probally be unaffected. ${ }^{56}$

Section 17 states the method of renewing a lost or destroyed certificate, and its provisions are substantially the same, although not as complete. as those of section 328 of the Civil Code. Two important differences, however, appear. In the first place, under the proposed section, the person seeking a new certificate must give a bond with sufficient surety to be approved by the court to protect the corporation or any person injured by the issuance of the new certificate from any liability which it or they may incur in case the old certificate remains outstanding. Secondly, the new

so It is a general rule that one cannot be deprived of his property by a forgery, so that ordinarily an owner may recover his certificates from one who holds them in reliance upon the spurions indorsement or may join him in a suit against the corporation to compel a transfer or retransfer on its books, according to the circumstances. If, however, the corporation has already issued new certificates to a transferee, the original owner has no remedy against persons who purchase them in good faith and for value. See 2 Cook on Corporations (7th ed.) $\S 370 ; 6$ Fletcher, Cyclopedia Corporations, $\S 3845$. 
act does not relieve the corporation from liability in damages to a person to whom the original certificate has been or shall be transferred for value without notice of the proceedings or of the existence of the new certificate. Under the existing law, a corporation is absolutely relieved from liability once the new certificate is issued. ${ }^{57}$ The last two sections have the advantage of obviating the possibility of injury, both by the giving of the bond and the retention of corporate liability. On the other hand, the code, as it now stands, sets forth more exactly than the proposed Act the requirements of notice of the action to renew and the necessary party defendants, and it would probably be well to incorporate that exactness in the new law to avoid possible confusion even at the expense of uniformity in what would be purely a procedural matter.

The remaining sections of the new law can be discussed summarily. Sections 18 and 19 state that the rules of the law merchant, as well as law and equity, are to govern in cases not specifically covered and that the purpose of the act is to make uniform the law upon the subject. Section 22 defines the terms used in the Act, while, more specifically, section 20 defines an indorsement and section 21, the person who by the certificate appears to be the owner. Section 23 applies the Act only to certificates issued after its adoption.

One thing might be noted in section 22. A purchaser is defined as including a pledgee or mortgagee. Stock would seem not to be included in the sort of property in California capable of being chattel mortgaged as it is not capable of manual delivery. ${ }^{58}$ Between the parties, however, the mortgage would be good. ${ }^{59}$ If the word mortgage is to be retained in the Uniform Act, it might be well to enlarge section 2955 of the Civil Code (defining property which can be mortgaged) to include stock. Otherwise the word should be eliminated from the Act to avoid needless litigation over

57 Two objections, it seems, may be made to the retention of corporate liability in case of lost certificates. How will it be possible for a corporation to know exactly how much outstanding stock it has if it is still accountable for that which has been lost and for which a new certificate has been issued following court proceedings? A corporation may well say that here especially it should be relieved, for obviously it will have had no hand in occasioning the loss. Then again indemnity bonds are expensive. Loss and destruction frequently occur. Bona fide dealers in outstanding certificates following reissues rarely appear. Therefore, to require a bond in every case is bad economically. In other words, the loss which may fall upon such a holder is so infrequent as not to justify the cost involved in the method designed to insure against it.

${ }_{58}$ Cal. Civ. Code, $\$ 2955$.

59 Cal. Civ. Code, $\$ 2793$. 
rules of construction as to the legislature's intent in employing the word.

Section 22 limits further the effect of the Uniform Act by defining the word "certificate" as used in the Act as meaning a "certificate of stock in a corporation organized under the laws of this state or of another state whose laws are consistent with this act." Thus transfers between individuals in a state which has the Act will not be governed by its provisions if the certificate represents shares in a corporation organized in a jurisdiction whose laws are not the same. In other words, a foreign corporation may properly refuse a transfer on its books, if the law of the jurisdiction under which it is organized would not give validity to the transaction whereby the stock was acquired.00

Nor will the Act have any extraterritorial effect. For example, a corporation organized in a state which has the Act would be justified in refusing to transfer stock to a person who has obtained an alleged title by means of a transfer which, although effective under the Act to pass title, would be ineffective by the laws of the state where it took place."

University of California

H. B. Seymour.

Berkeley, California.

60 Boston Safe Deposit \& Trust Co. v. Adams (1916) 224 Mass. 442, 113 N. E. 277, L. R. A. $1916 \mathrm{~F} 488$. But a state may properly prescribe such conditions as it sees fit on the right of a foreign corporation to do business withir: its borders, and one of these conditions may be that local law (say the Uniform Act) is to govern in the transfer of such corporation's stock. With reference to this principle in California see London, P. \& A. Bank v. Aronstein (1902) 117 Fed. 601, certiorari denied, (1902) 187 U. S. 641, 47 L. Ed. 345 (mem. dec.).

01 That is to say, suppose California has adopted the Act and Nevada has not. A sells his stock in a California corporation to $B$ and the sale takes place in Nevada. Under Nevada laws, let it be supposed, title did not pass but that under the Act what was done would have been sufficient. Nevada law will govern and the California corporation would be justified in refusing 2 transfer on its books. Barstow v. City Trust Co. (1914) 216 Mass. 330, 103 N. E. 911. 